\section{Autoantikörper gegen PCA-2}

W. Stöcker

Euroimmun Medizinische Labordiagnostika AG, Lübeck, Deutschland

Synonym(e) Autoantikörper geg
Purkinje-Zellen-Autoantikörper 2

Englischer Begriff Purkinje cell cytoplasmic autoantibodies 2

Definition Autoantikörper gegen ein 280-kDa-Protein der Purkinje-Zellen des Kleinhirns. Als Zielantigen wurde 2017 das Mikrotubuli-assoziierte Protein (MAP) 1B identifiziert.

Funktion - Pathophysiologie Das Autoantigen der PCA-2Antikörper wird sowohl in peripheren und zentralen Neuronen als auch, bei Antikörper-positiven Patienten, in Tumorgewebe exprimiert.

Analytik Zum Nachweis von Autoantikörpern gegen PCA-2 eignet sich der indirekte Immunfluoreszenztest (IIFT, - Immunfluoreszenz, indirekte) mit Gefrierschnitten von Primatenkleinhirn. Autoantikörper gegen PCA-2 zeigen eine Fluoreszenz des Purkinje-Zell-Zytoplasmas, die sich bis in die Dendriten erstreckt.
Im $>$ Western blot mit aufgetrenntem Kleinhirnextrakt kommt es zu einer Reaktion bei $280 \mathrm{kDa}$.

Untersuchungsmaterial Serum, Plasma oder Liquor.

Probenstabilität Autoantikörper sind bei $+4{ }^{\circ} \mathrm{C}$ bis zu 2 Wochen lang beständig, bei $-20^{\circ} \mathrm{C}$ über Monate und Jahre ; hinweg.

Diagnostische Wertigkeit PCA-2-Antikörper sind sehr selten, sie können den ersten Hinweis auf einen zugrunde liegenden Tumor geben. Sie sind mit der Limbus-/ Hirnstamm-Enzephalitis, der zerebellären Ataxie, dem Lambert-Eaton-myasthenischen Syndrom (LEMS), der autonomen und motorischen Neuropathie und häufig mit gynäkologischen Tumoren und dem kleinzelligen Bronchialkarzinom assoziiert; s. a. \ Autoantikörper gegen neuronale Antigene.

\section{Literatur}

Gadoth A, Kryzer TJ, Fryer J, McKeon A, Lennon VA, Pittock SJ (2017) Microtubule-associated protein 1B: Novel paraneoplastic biomarker. Ann Neurol 81(2):266-277

Vernino S, Lennon V (2000) New Purkinje cell antibody (PCA-2): marker of lung cancer-related neurological autoimmunity. Ann Neurol 47:297-305 